\title{
Assessing soil water repellency of a sandy field with visible near infrared spectroscopy
}

Article in Journal of Near Infrared Spectroscopy · December 2015

DOI: 10.1255/jnirs.1188

CITATIONS

3

6 authors, including:

\section{Maria Knadel}

Aarhus University

42 PUBLICATIONS 302 CITATIONS

SEE PROFILE

Lis Wollesen de Jonge

Aarhus University

223 PUBLICATIONS 3,606 CITATIONS

SEE PROFILE
READS

97
Federico Masis Melendez

Costa Rican Institute of Technology (ITCR)

8 PUBLICATIONS 16 CITATIONS

SEE PROFILE

Emmanuel Arthur

Aarhus University

75 PUBLICATIONS 401 CITATIONS

SEE PROFILE

Some of the authors of this publication are also working on these related projects: 


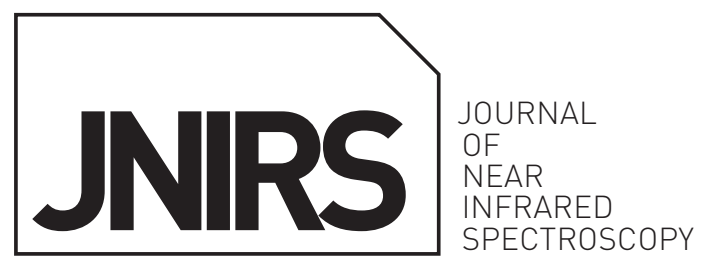

Special Issue: Near Infrared Spectroscopy of Soil

\title{
Assessing soil water repellency of a sandy field with visible near infrared spectroscopy
}

\author{
Maria Knadel, ${ }^{a *}$ Federico Masís-Meléndez, ${ }^{b}$ Lis Wollesen de Jonge, ${ }^{a}$ Per Moldrup, ${ }^{c}$ Emmanuel Arthur ${ }^{\mathrm{a}}$ and \\ Mogens Humlekrog Greve \\ aDepartment of Agroecology, Faculty of Science and Technology, Aarhus University, Blichers Allé 20, P0 Box 50, DK-8830 Tjele, Denmark. \\ E-mail: maria.knadel@agro.au.dk \\ ${ }^{\text {b} C o s t a ~ R i c a ~ I n s t i t u t e ~ o f ~ T e c h n o l o g y ~(I n s t i t u t o ~ T e c n o l o g i c o ~ d e ~ C o s t a ~ R i c a, ~ T E C), ~ C a r t a g o ~ 30101, ~ C o s t a ~ R i c a ~}$ \\ 'Department of Civil Engineering, Aalborg University, Sofiendalsvej 11, DK-9200 Aalborg SV, Denmark
}

Soil water repellency (WR) is a widespread phenomenon caused by aggregated organic matter (OM) and layers of hydrophobic organic substances coating the surface of soil particles. These substances have a very low surface free energy, reducing a soil's water attraction. There is focus on WR due to its effects on germination, root growth, liquid-vapour dynamics, surface erosion and leaching of chemicals through fingered flow paths. However, common techniques for measuring WR are time-consuming and expensive. Meanwhile, it is well established that visible near infrared (vis-NIR) spectroscopy is a reliable method for determining soil OM. Potentially it could therefore provide fast measurements of WR through autocorrelation with OM. The aim of this study was to test the feasibility of vis-NIR spectroscopy for estimating the WR of soils with a small gradient in soil organic carbon (SOC) and texture, and to evaluate the effect of soil pretreatment on the predictive ability of WR models. A total of 87 soil samples from an agricultural coarse sandy field in Denmark were analysed for SOC, particle size fractions, water content and WR. Soil samples were scanned with a vis-NIR sensor $(350-2500 \mathrm{~nm})$ after air- and oven-drying at $60^{\circ} \mathrm{C}$ and $105^{\circ} \mathrm{C}$. WR, expressed as liquid surface tension $\left(\mathrm{mN} \mathrm{m}^{-1}\right)$, was determined using the molarity of ethanol droplet test. Partial least squares regression models of SOC, texture and water content showed no predictive ability $\left(r^{2}\right.$ values between 0.10 and 0.51). However, successful models $\left(r^{2}=0.85\right)$ were generated for WR. The majority of bands important in the vis-NIR region of WR models were related to different components of $O M$ indicating that, across the investigated field, WR was related to specific hydrophobic components of soil $\mathrm{OM}$ rather than to the total amount of carbon. A lower prediction error of the WR model for soils dried at $105^{\circ} \mathrm{C}\left(1.93 \mathrm{~m} \mathrm{~N} \mathrm{~m}^{-1}\right)$ than at $60^{\circ} \mathrm{C}\left(2.52 \mathrm{~m} \mathrm{~N} \mathrm{~m}^{-1}\right)$ can be explained by a lower range of WR values for the soils dried at $105^{\circ} \mathrm{C}$. Moreover, a higher temperature reduced the number of absorption bands related to $\mathrm{OM}$, indicating a degradation of hydrocarbon groups and a more hydrophobic character of the soil.

Keywords: vis-NIR spectroscopy, PLSR, soil WR, liquid surface tensions

\section{Introduction}

Soil water repellency (WR) or hydrophobicity is a global phenomenon with a huge impact on soil hydraulic properties such as infiltration, evaporation, erosion and preferential flow. ${ }^{1}$ WR occurs on low-energy surfaces with weak attractions between water molecules of the solid-liquid interface. ${ }^{2}$ Coating of mineral surfaces by organic substances le.g. root exudates, microbial by-products and decomposed organic matter) and the presence of aggregate organic matter are the primary causes of WR. ${ }^{3-5}$

In most cases, strong correlations between soil organic matter (OM) and WR have been reported. ${ }^{6,7}$ In some cases, no correlation was found at all, 8,9 indicating that both quantity and quality (composition) of OM determines the degree of WR. For instance, a high diversity of different organic components such 
as humic, aliphatic and fatty acid structures or plant debris is associated with a pronounced WR. ${ }^{10,11}$

Further, the effect of soil drying temperature on potential WR is far from being understood. ${ }^{12}$ However, it is clear that oven-drying results in an increased hydrophobic character of soils, ${ }^{13,14}$ thus emphasising the importance of temperature pretreatment for WR determination. ${ }^{12}$ Moreover, studies on the effect of soil burning reported not only OM but also clay fractions as responsible for developing the hydrophobicity in soil. ${ }^{15,16}$

Soil WR can be determined with techniques such as the water drop penetration time test, molarity of ethanol droplet (MED) test, intrinsic sorptivity method, capillary rise method (CRM), sessile drop method (SDM) or sessile drop contact angle and Wilhelmy plate method (WPM). ${ }^{12,17}$ Most of these techniques are either difficult to use (intrinsic sorptivity), timeconsuming (SDM and WPM), overestimate WR (CRM) or do not allow subcritical WR (MED) to be quantified. ${ }^{12,17,18}$ Additionally, most of the techniques are challenged by both the chemical heterogeneity and surface roughness of the soil, which strongly limit their effectiveness.

Because of these challenges, an alternative technique for rapid determination of WR will be beneficial for various research disciplines. The new method should provide fast and reliable estimates of WR, facilitating the acquisition of highly dense data necessary for a better understanding of the causes and the consequences of this phenomenon in different soil types and across different scales.

Diffuse reflectance spectroscopy in the visible near infrared (vis-NIR) range $(350-2500 \mathrm{~nm}$ ) is an alternative technique to conventional wet chemistry analyses of soil. The application of vis-NIR spectroscopy is wide ranging and relevant for many soil properties, including chemical, physical and biological properties. ${ }^{19}$ This technique is faster than traditional soil analysis since it requires very little sample preparation. It does not involve chemicals and it is non-destructive. Moreover, several soil properties such as soil OM, texture and water content can be analysed simultaneously using spectroscopy. ${ }^{19}$ The application of vis-NIR spectroscopy to soil analyses is possible because spectra contain information on the organic and inorganic composition of soil. Molecules containing chemical bonds such as $\mathrm{C}-\mathrm{N}, \mathrm{N}-\mathrm{H}$ and $\mathrm{O}-\mathrm{H}$ are related to $\mathrm{OM}$ and predominate in this absorption region. ${ }^{20}$ For instance, accurate estimation of soil organic carbon (SOC) from NIR spectroscopy has been achieved in several studies. ${ }^{21-24}$ Information on the inorganic matter can be held for example by different types of metal oxides or minerals. Since SOC is present in the soil in the form of OM and is more commonly measured than $\mathrm{OM}, \mathrm{SOC}$ is what we will be using for quantitative analysis with vis-NIR spectroscopy. However, for qualitative analysis and assignment of the important absorption bands in calibration models we will refer to the different chemical bonds related to $\mathrm{OM}$. Even though WR is not a spectrally active soil component, the degree of WR is determined by the amount and type of OM. ${ }^{25-27}$ Thus, WR may potentially be determined using
vis-NIR spectroscopy through its co-variation with spectrally active OM components.

To the best of the authors' knowledge, only two studies ${ }^{6,28}$ have combined vis-NIR spectroscopy with WR analysis. Knadel et al. ${ }^{28}$ used WR as a proxy for OM quality to supplement the characterisation of surface functionality of four Danish soils in a study on soil moisture effects on vis-NIR spectra. They reported that changes in WR curve types (WR as a function of water content) indicated and reflected a clear difference in $\mathrm{OM}$ quantity and possibly quality among the investigated soils. The study by Kim et al. ${ }^{6}$ used vis-NIR spectroscopy to predict WR for 288 soil samples from a soil survey in New Zealand across different soil types with a wide range in SOC and texture. They investigated soil samples covering 10 soil orders with five sampling sites per order and five samples per sampling site. Moderately accurate predictions of WR $\left(R^{2}=0.61\right.$, root mean square error of prediction $=0.59 \%$ ) for air-dried soils were obtained and were explained by a correlation between WR and SOC.

The aim of the present study was to investigate the feasibility of using vis-NIR spectroscopy to determine WR for soil samples originating from a field with a low variability in soil properties. This study explored additionally the effect of differing drying temperatures $\left(60^{\circ} \mathrm{C}\right.$ and $\left.105^{\circ} \mathrm{C}\right)$ on the ability of vis-NIR spectroscopy partial least squares (PLS) regression models to predict WR. A range of soil properties including SOC, clay, silt, fine sand, coarse sand, total sand and water contents were also predicted in order to verify the role of various soil properties in vis-NIR spectroscopy models of WR.

\section{Materials and methods Study area}

Bulk soil samples used in this study originated from the work by Masis-Meléndez et al. ${ }^{29}$ The study field of 1.6 ha is located in Jyndevad, southern Denmark (Figure 1), and represents a site with a small gradient in SOC and texture. The soil is classified as a Typic Haplohumod. A total of 87 topsoil samples $(0-20 \mathrm{~cm})$ were collected on a $15 \mathrm{~m}$ grid. Soil particle size fractions were determined using wet-sieving and hydrometer methods. ${ }^{30}$ Clay was defined as particles smaller than $0.002 \mathrm{~mm}$, silt from $0.002 \mathrm{~mm}$ to $0.05 \mathrm{~mm}$, fine sand from $0.05 \mathrm{~mm}$ to $0.1 \mathrm{~mm}$, coarse sand from $0.1 \mathrm{~mm}$ to $0.2 \mathrm{~mm}$ and total sand from $0.05 \mathrm{~mm}$ to $0.2 \mathrm{~mm}$. SOC was analysed at $950^{\circ} \mathrm{C}$ with a FLASH 2000 organic elemental analyser coupled to a thermal conductivity detector (Thermo Fisher Scientific, Waltham, MA, USA). Prior to the measurements, samples were ground. Approximately $50 \mathrm{mg}$ of each soil sample was used for the SOC analysis.

\section{Water repellency measurements}

Soil sample $(<2 \mathrm{~mm})$ pretreatment to evaluate the increment of hydrophobicity included three conditions: (i) air-dryness, (ii) oven-dryness at $60^{\circ} \mathrm{C}$ for $48 \mathrm{~h}$ and (iii) oven-dryness at $105^{\circ} \mathrm{C}$ for $48 \mathrm{~h}$. For WR measurements, $5 \mathrm{~g}$ of soil was put into a 


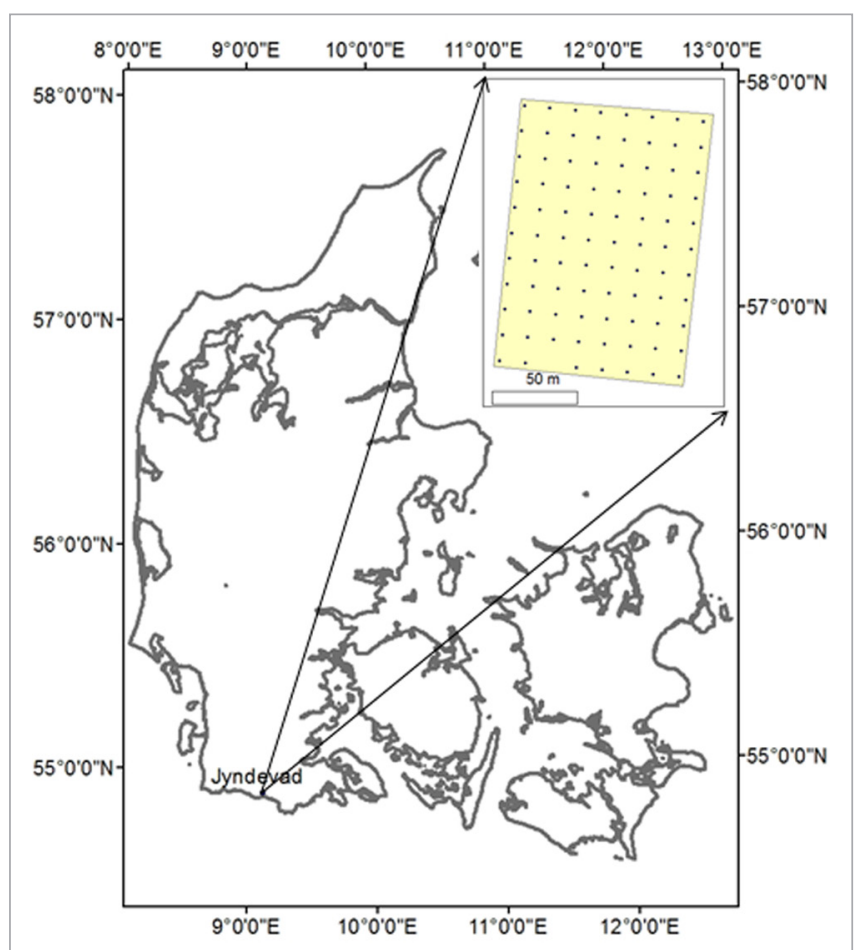

Figure 1. The location of the field study (Jyndevad, Denmark).

plastic container ( $410 \mathrm{~mm}$ diameter by $5 \mathrm{~mm}$ deep) and the soil surface made uniform by placing a $120 \mathrm{~g}$ weight over the sample surface for $2 \mathrm{~min}$. The degree of WR was determined at $20^{\circ} \mathrm{C}$ for the pretreated samples using the MED test ${ }^{16,31}$ and given as the maximum percentage ethanol of a $60 \mu \mathrm{L}$ aqueous ethanol droplet that can stay on the plane soil surface for at least $5 \mathrm{~s}$. Aqueous ethanol solutions from $0.01 \mathrm{~m}^{3} \mathrm{~m}^{-3}$ to $0.60 \mathrm{~m}^{3} \mathrm{~m}^{-3}$ in $0.01 \mathrm{~m}^{3} \mathrm{~m}^{-3}$ steps were used to reduce the surface tension of deionised water $\left(72.1 \mathrm{mN} \mathrm{m}^{-1}\right)$. When a droplet of water infiltrates within $5 \mathrm{~s}$, the soil is assumed to be non-water repellent and the resultant contact angle is specified to be equivalent to $90^{\circ}$. High ethanol concentrations (i.e. low surface tension) suggest a more pronounced WR. For the repellent soils the maximum ethanol concentration ( $M$, mol $L^{-1}$ ) required for complete infiltration of the droplet after $5 \mathrm{~s}$ was converted to liquid surface tension $(\gamma)$ by means of $\gamma=61.05-14.75 \ln (M+0.5)^{2}$

\section{Spectroscopic measurements}

A benchtop vis-NIR spectrophotometer (LabSpec ${ }^{\circledR} 5100$ ) equipped with a high-intensity Muglight probe (ASD Inc., Boulder, CO, USAl was used to obtain soil spectra within the spectral range $350-2500 \mathrm{~nm}$. In the first step soil samples were scanned after air-drying and sieving $(<2 \mathrm{~mm})$. In order to test the effect of temperature on vis-NIR predictions of WR, soils were additionally scanned after oven-drying (for $48 \mathrm{~h}$ ) at $60^{\circ} \mathrm{C}$ and $105^{\circ} \mathrm{C}$. For all temperature treatments two subsamples of each sample were scanned and an average of the two scans per sample was used in the further analysis. Details of the scanning protocol and instrumentation can be found in Knadel et al. ${ }^{32}$

\section{Principal component analysis (PCA)}

PCA was applied to the entire dataset including spectra of air-dried and oven-dried soils in order to illustrate the effects of sample drying on soil spectra and properties. Principal component (PC) scores were calculated to describe relationships and patterns in the samples and were related to the variables with high loadings located on the same PC. Loadings were used to indicate the contribution of individual variables (wavelengths) along the PC.

\section{Multivariate data analysis}

PLS regression was carried out using Unscrambler X 10.1 software (Camo ASA, Oslo, Norway) to correlate soil spectra with the soil properties of interest. Soil properties were determined from apparent absorbance $(A=\log (1 / R)$, where $A$ is absorbance and $R$ is reflectance). Despite a wide range of available modelling methods, PLS regression was chosen since it has produced satisfactory results for NIR calibrations on Danish soils. ${ }^{24,32}$ Segmented cross-validation was used in the analysis with two geographically neighbouring samples per segment. Thus, segments were left out of the dataset one at a time and the model was calibrated on the remaining samples, so that each segment was omitted from the analysis once. The validation residual variance was then computed from the prediction residual. ${ }^{33}$

To improve calibration results, different spectral pretreatments including derivatives (first and second SavitzkyGolay derivatives with a second-order polynomial, over 30 smoothing points) and scatter corrections (standard normal variate and multiplicative scatter correction) were tested. ${ }^{32}$ The best treatment was considered to be the one resulting in a model with the lowest root mean square error of cross-validation (RMSECV) and the highest $r^{2}$ for the validation dataset ladjusted $R$-squared showing the goodness of fit expected for future predictions), and a ratio of performance to interquartile range $(R P I Q)$ was additionally calculated as the difference between the third interquartile and the first interquartile divided by RMSECV, as proposed by Bellon-Maurel and McBratney. ${ }^{34}$

\section{Results and discussion}

The study site is a relatively homogeneous field dominated by sandy soils with an average total sand fraction of $90 \%$, with a low SOC range $(1.4-2.5 \%)$ and an average water content of $0.006 \mathrm{~g} \mathrm{~g}^{-1}$ (Table 1).

For the MED test, the maximum surface tension that can be determined is $72.1 \mathrm{mN} \mathrm{m}^{-1}$ (i.e. the surface tension of water). Therefore, soils with values above $72.1 \mathrm{mN} \mathrm{m}^{-1}$ are considered as non-hydrophobic ${ }^{35}$ which was the case in this study. In contrast, WR was enhanced (i.e. decreasing surface tension) after oven-drying the soils. Soils dried at $60^{\circ} \mathrm{C}$ were less water repellent laverage $\gamma=59.44 \mathrm{mN} \mathrm{m}^{-1}$ ) than samples dried at $105^{\circ} \mathrm{C}\left(\gamma=48.40 \mathrm{mN} \mathrm{m}^{-1}\right)$, confirming that WR increases for higher drying temperatures (Table 1). This is in agreement 
Table 1. Summary statistics of soil organic carbon, particle size distribution and water content measured for air-dried soils and water repellency for the 87 samples. $^{\mathrm{a}}$

\begin{tabular}{|l|c|c|c|c|c|c|c|c|c|}
\hline & $\begin{array}{c}\text { SOC } \\
(\%)\end{array}$ & $\begin{array}{c}\text { Clay, } \\
<2 \mu \mathrm{m} \\
(\%)\end{array}$ & $\begin{array}{c}\text { Silt, } \\
2-50 \mu \mathrm{m} \\
(\%)\end{array}$ & $\begin{array}{c}\text { Fine sand, } \\
\mathbf{5 0 - 1 0 0 \mu \mathrm { m }} \\
(\%)\end{array}$ & $\begin{array}{c}\text { Coarse sand, } \\
\mathbf{1 0 0 - 2 0 0 0 \mu \mathrm { m }} \\
(\%)\end{array}$ & $\begin{array}{c}\text { Total sand, } \\
\mathbf{5 0 - 2 0 0 0 \mu \mathrm { m }} \\
(\%)\end{array}$ & $\begin{array}{c}W C \\
\left(\mathbf{g ~ g}^{-1}\right)\end{array}$ & $\begin{array}{c}\text { WR60 } \\
\left(\mathrm{mN} \mathrm{m}^{-1}\right)\end{array}$ & $\begin{array}{c}\text { WR105 } \\
\left(\mathrm{mN} \mathrm{m}^{-1}\right)\end{array}$ \\
\hline Mean & 1.82 & 4.35 & 4.84 & 4.03 & 86.78 & 90.81 & 0.006 & 59.44 & 48.40 \\
\hline Max. & 2.49 & 5.22 & 5.95 & 7.33 & 88.84 & 91.88 & 0.009 & 71.27 & 56.55 \\
\hline Min. & 1.38 & 3.65 & 4.04 & 2.37 & 83.39 & 89.78 & 0.003 & 48.24 & 41.54 \\
\hline SD & 0.21 & 0.40 & 0.39 & 1.10 & 1.23 & 0.50 & 0.001 & 7.16 & 4.62 \\
\hline Q1 & 1.67 & 4.00 & 4.30 & 3.31 & 86.05 & 90.37 & 0.005 & 53.23 & 44.51 \\
\hline Q3 & 1.95 & 4.50 & 4.80 & 4.45 & 87.74 & 91.11 & 0.006 & 63.58 & 53.23 \\
\hline
\end{tabular}

aSOC, soil organic carbon; WC, water content; WR60, water repellency lexpressed as surface tension) after drying at $60^{\circ} \mathrm{C}$; WR 105, water repellency (expressed as surface tension) after drying at $105^{\circ} \mathrm{C} ; S D$, standard deviation; Q1, first interquartile; $Q 3$, third interquartile.

with Kawamoto et al., ${ }^{36}$ who reported higher WR for soil samples oven-dried at $105^{\circ} \mathrm{C}$ than at $60^{\circ} \mathrm{C}$ or air-dried at $20^{\circ} \mathrm{C}$.

In order to be able to predict WR from vis-NIR spectra it is important that WR is correlated to other spectrally active soil properties. Table 2 presents a correlation matrix for all investigated soil properties and WR. Soil WR for samples dried at $60^{\circ} \mathrm{C}$ (WR60) and $105^{\circ} \mathrm{C}$ (WR105) were both negatively correlated with the fine sand fraction $(r=-0.66)$. There was a positive correlation between WR and clay content $(r=0.52)$, a low negative correlation with SOC ( $r=-0.31$ to -0.33$)$ and no correlations with water content $(r \leqslant-0.10)$. The correlation between WR and SOC was lower than expected, even though higher OM contents in sandy soils were found to induce severe WR. Thus, the possible correlation between WR and vis-NIR spectra may be mainly explained by the autocorrelation between WR and clay.

\section{Principal component analysis}

PCA was performed on absorption spectra without any additional spectral pretreatments. The first three PCs of the PCA explained $67 \%, 23 \%$ and $9 \%$ of the variation, respectively, amounting to $99 \%$ of the total variation for the entire dataset of air- and oven-dried soil samples. Figure 2(a) illustrates the PC1 versus PC3 score plot, with the scores grouped according to the sample treatment lair-dried and oven-dried at $60^{\circ} \mathrm{C}$ and $105^{\circ} \mathrm{C}$ ). PC3 distinguishes between the temperature treatments. Drying the soils at $105^{\circ} \mathrm{C}$ clearly altered the spectrally active components of the soil, resulting in a distinct and more separate group along the negative values of PC3 [Figure 2(a)]. Oven-drying the soils at $60^{\circ} \mathrm{C}$ apparently did not change their properties significantly compared with air-drying since all results after the two temperature treatments were located on the positive side of the PC3 axes, overlapping in spectral space, thus indicating similarities The corresponding loading plot reveals the important wavebands responsible for sample grouping along PC3 [Figure 2(b)]. The highest loadings were located around $1930 \mathrm{~nm}$ and can be assigned to different $\mathrm{OM}$ constituents such as $\mathrm{C}=\mathrm{O}$ bonds, ${ }^{19}$ cellulose, lignin or pectin. ${ }^{37}$ The $\mathrm{O}-\mathrm{H}$ bond in water can be detected in the region between $1900 \mathrm{~nm}$ and $1930 \mathrm{~nm}^{37}$ and can be a good indicator of changes related to the heating and drying of the samples. Another significant loading around $820 \mathrm{~nm}$ is related to $\mathrm{C}-\mathrm{H}$

Table 2. Correlation matrix of the soil properties for the 87 samples. $^{\text {a }}$

\begin{tabular}{|l|c|c|c|c|c|c|c|c|c|}
\hline & SOC & Clay & Silt & $\begin{array}{c}\text { Fine } \\
\text { sand }\end{array}$ & $\begin{array}{c}\text { Coarse } \\
\text { sand }\end{array}$ & $\begin{array}{c}\text { Total } \\
\text { sand }\end{array}$ & WC & WR60 & WR105 \\
\hline SOC & 1.00 & & & & & & & & \\
\hline Clay & 0.16 & 1.00 & & & & & & & \\
\hline Silt & 0.21 & -0.20 & 1.00 & & & & & \\
\hline Fine sand & 0.52 & -0.26 & 0.33 & 1.00 & & & & \\
\hline Coarse sand & -0.58 & -0.03 & -0.55 & -0.91 & 1.00 & & & \\
\hline Total sand & -0.29 & -0.64 & -0.62 & -0.05 & 0.45 & 1.00 & & & \\
\hline WC & 0.46 & 0.11 & 0.17 & 0.13 & -0.20 & -0.23 & 1.00 & & \\
\hline WR60 & -0.33 & 0.52 & -0.26 & -0.66 & 0.50 & -0.21 & -0.10 & 1.00 & \\
\hline WR105 & -0.31 & 0.53 & -0.21 & -0.63 & 0.46 & -0.26 & -0.05 & 0.92 & 1.00 \\
\hline
\end{tabular}

aSOC, soil organic carbon; WC, water content; WR60, water repellency (expressed as surface tension) after drying at $60^{\circ} \mathrm{C}$; WR 105, water repellency (expressed as surface tension) after drying at $105^{\circ} \mathrm{C}$. 

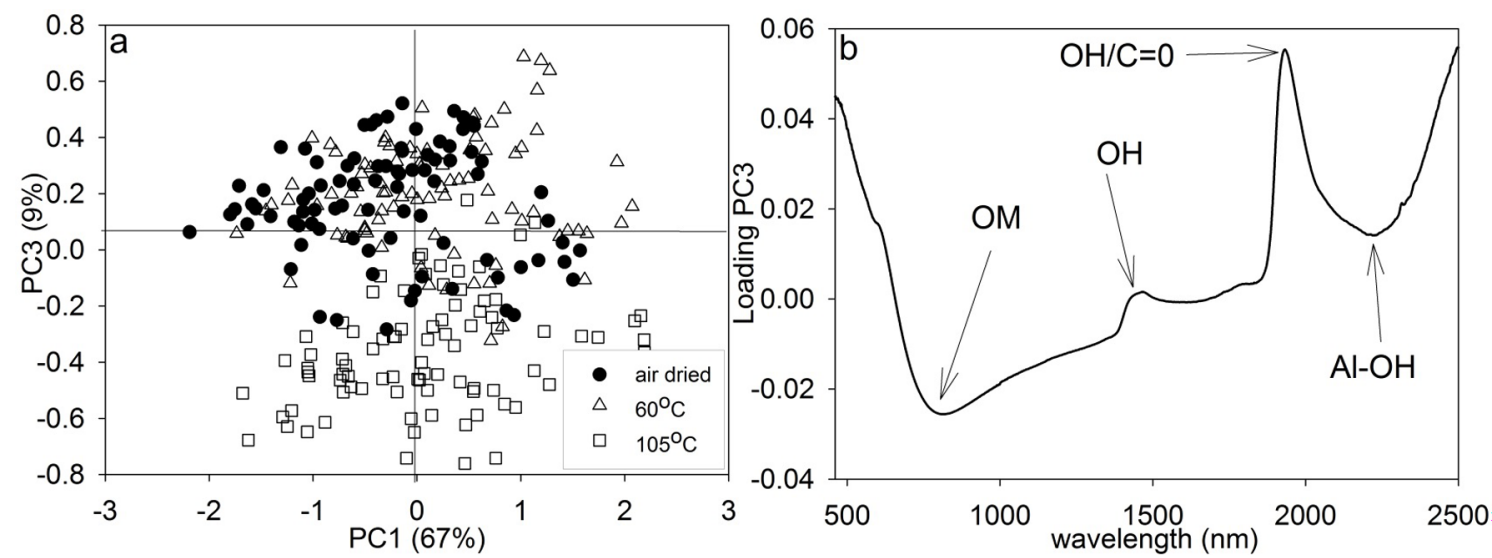

Figure 2. (a) Principal components score plot (PC1 versus PC3 of absorption spectra) marked according to temperature treatment and (b) the corresponding loading plot for the three temperature treatments with the most important bands indicated.

bonds in aromatics, ${ }^{19}$ implying possible changes to OM caused by temperature changes. Less pronounced loadings in PC3 around $1400 \mathrm{~nm}$ and $2200 \mathrm{~nm}$ can be attributed to water. The absorption feature around $1400 \mathrm{~nm}$ could either be for bound water incorporated in the mineral lattice or be for free water occupying soil pores. ${ }^{37}$ However, since soil samples used in this study were not moist, higher loading at $1400 \mathrm{~nm}$ indicates changes in water content within the mineral lattice as a result of sample drying. Hygroscopic or adsorbed water which exists on the surface areas of clay minerals in the form of a thin layer shows a typical absorption band near $2200 \mathrm{~nm}^{37}$ and is also present in the PC3 loading, confirming again that PCA captures the effect of drying on the amount of water present in the soils.

\section{Qualitative analysis of soil spectra}

The effect of the drying temperature on the vis-NIR spectrum for one selected soil sample is shown in Figure 3. The spectra of no other samples are shown since the remainder exhibited a similar trend. In order to highlight the important information in the spectra and ease the comparison, absorption

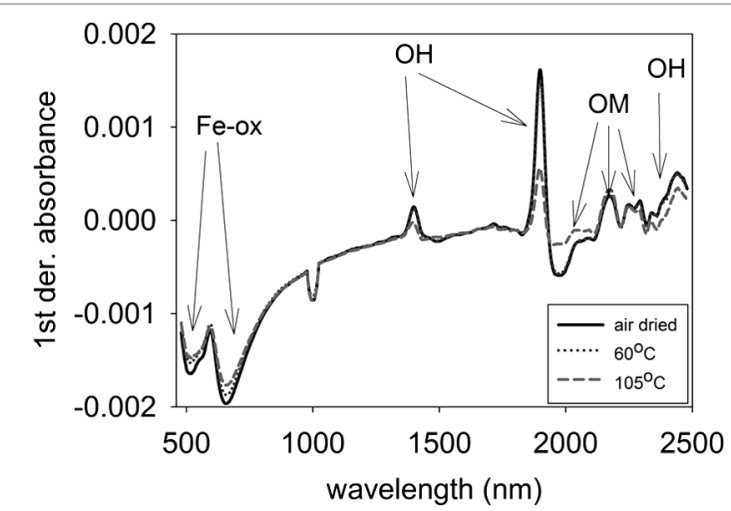

Figure 3. Spectra (first derivative) of a chosen soil sample after three temperature treatments lair-dried and oven-dried at $60^{\circ} \mathrm{C}$ and $105^{\circ} \mathrm{Cl}$. spectra were transformed to the first Savitzky-Golay derivative (second-order polynomial with 15 smoothing points). As also indicated by the score plots, there was very little visible difference between the spectra of soils that were air-dried or oven-dried at $60^{\circ} \mathrm{C}$.

The most significant decrease in absorbance with increase in temperature occurred after oven-drying at $105^{\circ} \mathrm{C}$ in the spectral region near $1900 \mathrm{~nm}$. Absorption in this waveband can be assigned to molecular water, ${ }^{38}$ and, as expected, its value decreased with increasing temperature. A pronounced decrease in absorbance after drying the soils at $105^{\circ} \mathrm{C}$ can be seen in the region between $1950 \mathrm{~nm}$ and $2114 \mathrm{~nm}$. Multiple wavelengths in this range relate to different $\mathrm{OM}$ components such as sugar, starch, cellulose, lignin and protein at 1950, 2068 and $2111 \mathrm{~nm},{ }^{37}$ phenolics at $1961 \mathrm{~nm},{ }^{19} \mathrm{CO}\left(\mathrm{NH}_{2}\right)_{2}$ at $2030 \mathrm{~nm}$ and $2070 \mathrm{~nm},{ }^{39}$ amides at $2033 \mathrm{~nm}$ and amine at $2060 \mathrm{~nm} .{ }^{19}$ Higher drying temperatures resulted in lower absorbance values in this region, possibly due to selective degradation of the listed OM components.

A less pronounced reduction of absorbance values with drying can be observed in the visible part of the spectrum at $517 \mathrm{~nm}$ and $665 \mathrm{~nm}$ (corresponding to the absorption of iron oxides). $\mathrm{OM}$ has also been reported to be spectrally active in the region between $570 \mathrm{~nm}$ and $700 \mathrm{~nm} .{ }^{40}$ Other regions altered by temperature can be seen at $1400 \mathrm{~nm}$ (corresponding to the absorption of free water) and between 2340 and $2447 \mathrm{~nm}$ Irelated to $\mathrm{OH}$ stretch in clay minerals and various OM components such as aliphatic $\mathrm{C}-\mathrm{H}$, cellulose and lignin). ${ }^{37}$

\section{Multivariate data analysis}

\section{Prediction results}

PLS regression models for SOC, particle size fractions and water content were generated using spectra of air-dried soils [Figure 4(a)-(g)]. Models for SOC, sand fractions and water content were generated using absorption spectra without additional pretreatments, whereas models for silt and clay used multiplicative scatter correction and first derivative spectra, respectively. None of these models showed predictive 

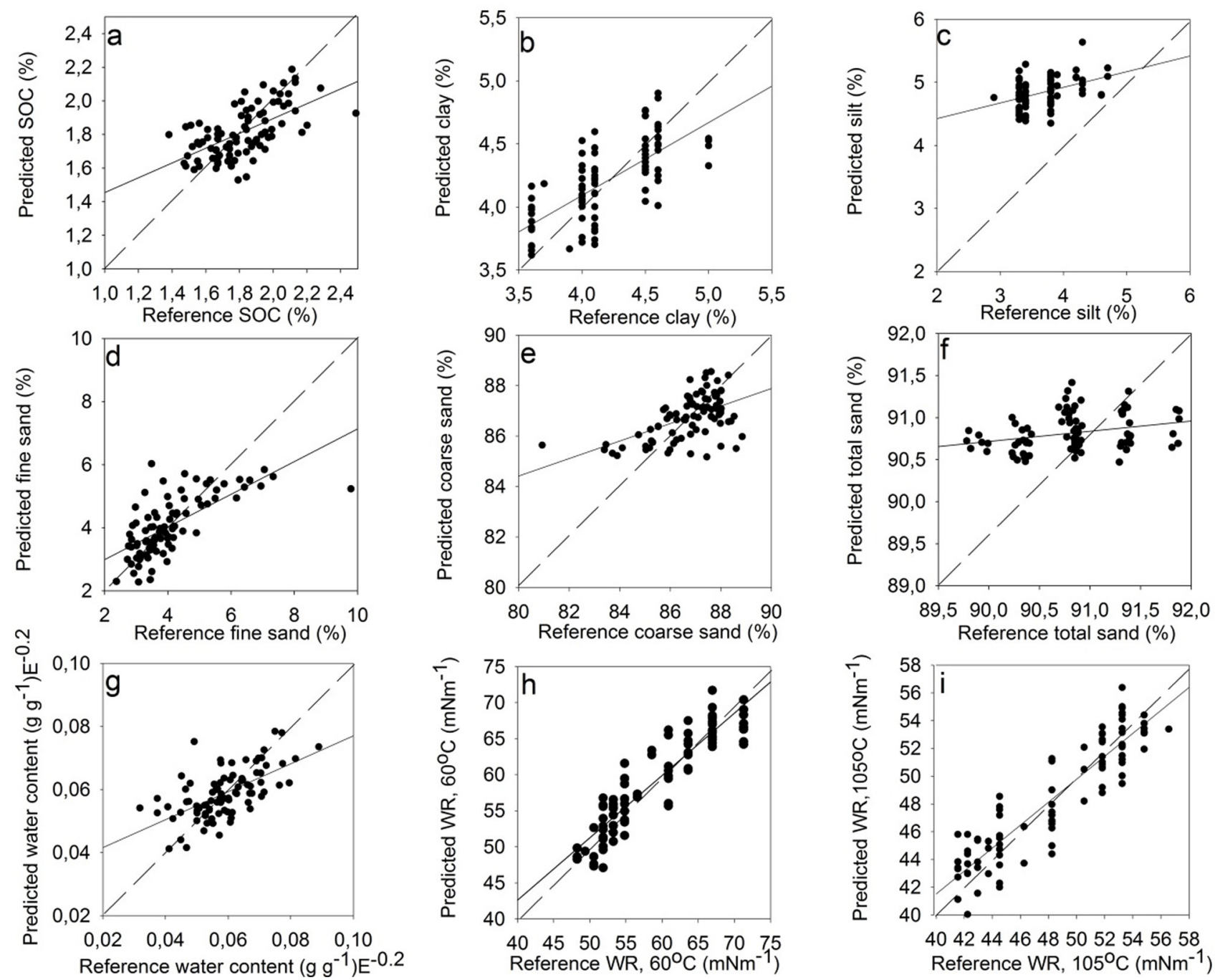

Figure 4. Partial least squares regression results (cross-validation) of selected soil properties: (a) SOC, (b) clay, (c) silt, (d) fine sand, (e) coarse sand, (f) total sand, (g) water content of air-dried soil, (h) WR after drying at $60^{\circ} \mathrm{C}$ and (i) WR after drying at $105^{\circ} \mathrm{C}$. The degree of WR increases with a decrease in surface tension $\left(\mathrm{mN} \mathrm{m}^{-1}\right)$.

abilities, with $r^{2}$ values below 0.51 (Table 3). The poor performance of the vis-NIR models was a consequence of the low variation in the investigated soils. The standard deviation (SD) values of the soil properties were relatively small (Table 1), and, as reported by Stenberg et al., ${ }^{19}$ the overall variation affects the prediction performance of calibration models. A range of studies have found that the lower the SD the lower the $R^{2}$ values for SOC and texture models. ${ }^{19}$ Despite a large number of absorption bands related to organic and mineral matter in soil, the signals in the vis-NIR region are often weak since they represent the combinations and overtones of the fundamental vibrations in the mid-infrared region. The signals are especially weak when only small amounts of these soil constituents are present. Moreover, this dataset had a very high mean sand content of $90.8 \%$ (Table 1). The scattering effect caused by sandy soils may mask the signals from OM, which can further lead to a low predictive ability of vis-NIR spectroscopy models for SOC content. Stenberg et al. ${ }^{19}$ also reported on the differences in the vis-NIR spectroscopy calibration performance for the SOC content of different textural classes. Those authors showed that datasets containing sandy soils had the lowest $r^{2}$ values for SOC predictions with values as low as 0.40, which is in line with our findings.

Models for WR lusing absorption spectra with no pretreatments) were generated from spectra of oven-dried soils at $60^{\circ} \mathrm{C}$ and $105^{\circ} \mathrm{C}$ [Figure $4(\mathrm{~h})$ and (i), respectively]. Successful results were obtained for both WR models (Table 3 ). The model based on spectra of soils dried at $60^{\circ} \mathrm{C}$ resulted in RMSECV $=2.52 \mathrm{mN} \mathrm{m}^{-1}, r^{2}=0.85$ and $R P / Q=4.1$. Further drying the soils at $105^{\circ} \mathrm{C}$ improved WR prediction with RMSECV $=1.93 \mathrm{mN} \mathrm{m}^{-1}, r^{2}=0.85$ and $R P I Q=4.5$ (Table 3). The higher precision of the WR prediction models obtained can be attributed partly to WR having a wider range and variation than any of the other soil properties investigated (Table 1).

Despite unsatisfactory prediction results for all of the soil properties, robust models of WR were generated, indicating 
Table 3. Partial least squares regression (cross-validation) results. ${ }^{\mathrm{a}}$

\begin{tabular}{|c|c|c|c|c|c|}
\hline & RMSECV & $r^{2}$ & Bias & $R P I Q$ & $L V$ \\
\hline $\operatorname{SOC}(\%)$ & 0.16 & 0.39 & -0.004 & 1.7 & 6 \\
\hline Clay $(\%)$ & 0.29 & 0.51 & 0.002 & 1.7 & 5 \\
\hline Silt (\%) & 0.36 & 0.17 & 0.002 & 1.4 & 5 \\
\hline Fine sand (\%) & 0.89 & 0.50 & -0.008 & 1.3 & 4 \\
\hline Course sand (\%) & 1.14 & 0.32 & 0.008 & 1.5 & 4 \\
\hline Total sand (\%) & 0.48 & 0.10 & 0.004 & 1.5 & 3 \\
\hline$W C\left(\mathrm{~g} \mathrm{~g}^{-1}\right)$ & 0.0008 & 0.38 & -0.001 & 1.2 & 5 \\
\hline WR60 $\left(\mathrm{mN} \mathrm{m}^{-1}\right)$ & 2.52 & 0.85 & -0.02 & 4.1 & 7 \\
\hline WR105 (mN m $\left.{ }^{-1}\right)$ & 1.93 & 0.85 & 0.02 & 4.5 & 7 \\
\hline
\end{tabular}

aSOC, soil organic carbon; WC, water content; WR60, water repellency (expressed as surface tension) after drying at $60^{\circ} \mathrm{C}$; WR 105 , water repellency (expressed as surface tension) after drying at $105^{\circ} \mathrm{C} ; R M S E C V$, root mean square error of cross-validation; $R P I Q$, ratio of interquartile range (Q3-Q1) to RMSECV; $L V$, latent variables.

that the successful determination of WR was possible due to its autocorrelation with other spectrally active soil properties or components present in the soil, but not investigated here.

As indicated by other studies, even though WR is related to the soil OM content, it is more its quality than its quantity that is responsible for the hydrophobic character of soil. ${ }^{10,11}$ Not all soil carbon compounds are hydrophobic and WR can thus be related to one or a few particular types of carbon rather than to the total carbon content. ${ }^{7}$ The PLS results from our study confirm that it is not the total amount of SOC that is the driving factor for WR. However, since no detailed data on the quality of the OM or type of SOC are available in this study, we can only draw a conclusion on the basis of the qualitative analysis of regression coefficients from prediction models to find spectrally active functional groups of soil OM components that explain the variation in WR.

\section{Qualitative analysis of regression coefficients}

Normalised regression coefficients from prediction models of WR60 and WR105 are presented in Figure 5. As explained above, the best models for WR were generated using absorption spectra with no spectral pretreatments and seven factors. Because of poor prediction results for other soil properties, their regression coefficients will not be discussed.

The shapes of the WR regression coefficient curves are for the most part similar (Figure 5). Nevertheless, distinct differences in the regions that can be assigned mainly to OM can be observed for both coefficients. Signals related to iron oxides are present in the visible part of the spectrum laround $620 \mathrm{~nm}$ ), with a higher intensity for the soils dried at $105^{\circ} \mathrm{C}$. A broad band near $853 \mathrm{~nm}$ related to $\mathrm{C}-\mathrm{H}$ bonds is also visible. Lower values of the regression coefficient in this region for the soils dried at $105^{\circ} \mathrm{C}$ indicate a lower content of molecules containing $\mathrm{C}-\mathrm{H}$ bonds. The wide band in the region 1000$1490 \mathrm{~nm}$ is also present in the coefficients from both models, with more pronounced intensities for the soils dried at $60^{\circ} \mathrm{C}$. This region reflects the presence of multiple $\mathrm{OM}$ components such as macromolecules of cellulose, wax, lignin and protein, ${ }^{37}$ containing primary amine groups $(\mathrm{N}-\mathrm{H})$, aromatics $(\mathrm{C}-\mathrm{H})$, alkyl $(\mathrm{C}-\mathrm{H})^{19}$ and carbonyl $(\mathrm{C}=\mathrm{O}) .{ }^{39}$ A pronounced peak around $1950-2000 \mathrm{~nm}$ can be observed for the soils dried at $60^{\circ} \mathrm{C}$ and can be assigned to $\mathrm{OM}$ components and $\mathrm{OH}$ in clay minerals. After drying at higher temperatures, this band shifted to lower wavelengths at around $1930 \mathrm{~nm}$ and could be assigned to carboxylic acid. ${ }^{19}$ Two more features related to OM can be found in the regression coefficient of the WR model based on soils dried at $60^{\circ} \mathrm{C}$. Close to $2279 \mathrm{~nm}$ a band related to hydrocarbon groups $\left(\mathrm{C}-\mathrm{H}, \mathrm{CH}_{2}, \mathrm{CH}_{3}\right)$ can be observed and a less pronounced band near $2330 \mathrm{~nm}$ related to $\mathrm{CH}_{2}$ and $\mathrm{COO}$ of cellulose and lignin. ${ }^{37}$ The presence of aliphatic $\mathrm{C}-\mathrm{H}$ groups has been reported to cause WR in soils. ${ }^{7}$ After drying the soils at $105^{\circ} \mathrm{C}$ a new feature can be observed at $2193 \mathrm{~nm}$ which was in an earlier study ${ }^{37}$ assigned to amide II (C-N, N-H) and protein. After drying at the higher temperature only one broad band between $2309 \mathrm{~nm}$ and $2348 \mathrm{~nm}$ is visible in the regression coefficient instead of the two features near $2297 \mathrm{~nm}$ and $2330 \mathrm{~nm}$ after drying at $60^{\circ} \mathrm{C}$. In this region several bands have previously been reported to be related to $\mathrm{OM}^{41}$ but also to clay minerals (illite). ${ }^{19}$

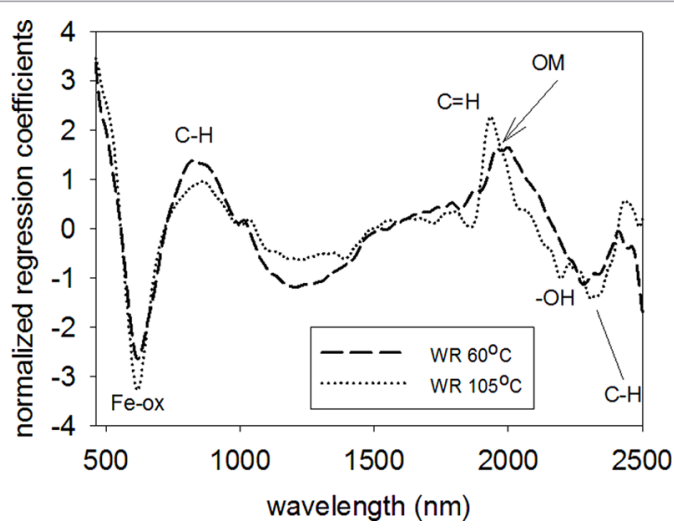

Figure 5. Regression coefficients from SOC (for air-dried soils) and WR (for oven-dried soils at $60^{\circ} \mathrm{C}$ and $105^{\circ} \mathrm{C}$ ) calibration models. 


\section{Conclusions}

WR is caused by the presence of hydrophobic agents on grain surfaces of minerals. It is often developed in sandy soils due to their small specific surface areas which are easily coated by hydrophobic substances. Even though WR is not an active soil component in the vis-NIR spectral region, the degree of WR can be related to the amount and type of soil OM and also clay fractions. Thus, we hypothesised that WR can be determined using vis-NIR spectroscopy through its co-variation with spectrally active carbon or/and clay.

The investigated dataset comprised soil samples originating from a sandy-textured field with a low variability in soil properties. Sandy fields can generally be simplified as homogeneous media; however, they may be subject to field-scale variation induced by changes in both the quantity and the quality of soil OM, resulting in pronounced variations in WR. Thus, field-based studies can provide a valuable input to a better understanding of the processes responsible for WR development.

Despite low variability in the investigated soil properties (SOC, clay, silt, sand and water content), a pronounced gradient in WR was reported. Moreover, the PLS calibration models of WR outperformed significantly those of the remaining soil properties. The good predictive ability of the WR models could not be attributed to total organic carbon or clay since their vis-NIR calibration models showed no predictive ability. Successful predictions of WR can be party explained by its wider range and variation compared with other soil properties. Additional detailed analyses of regression coefficients indicated that multiple bands assigned to hydrocarbon groups, including aliphatic $\mathrm{C}-\mathrm{H}$, and related to different components of $\mathrm{OM}$ were located along the entire vis-NIR spectrum of WR calibration models. The results indicate that across the investigated field WR was related to specific hydrophobic components of soil OM rather than to the total amount of carbon.

Vis-NIR spectroscopy proved to be a fast and reliable method for WR determination at a field scale. The ability to measure and predict many samples in a short time enables detailed analyses of the extent of WR across fields and will further enable more comprehensive studies to better understand its causes and consequences. Further studies will include a wider range of soil types sampled across various scales of geographic regions. Additionally, detailed information on the quality of SOC will be necessary in order to distinguish the contribution from the total SOC content and its hydrophobic components when determining WR using vis-NIR spectroscopy.

\section{Acknowledgements}

Financial support for this work came from the soil-spec project funded by the GUDP programme (Grønt Udviklings- og Demonstrationsprogram) under the Danish Ministry of
Food, Agriculture, and Fisheries and by the Danish Pesticide Leaching Assessment Programme (www.pesticidvarsling.dk).

\section{References}

1. N. Jarvis, A. Etana and F. Stagnitti, "Water repellency, near-saturated infiltration and preferential solute transport in a macroporous clay soil", Geoderma 143, 223 (2008). doi: http://dx.doi.org/10.1016/j. geoderma.2007.11.015

2. J.L. Roy and W.B. McGill, "Assessing soil water repellency using the molarity of ethanol droplet (MED) test", Soil Sci. 167, 83 (2002). doi: http://dx.doi. org/10.1097/00010694-200202000-00001

3. I. Atanassova and S.H. Doerr, "Organic compounds of different extractability in total solvent extracts from soils of contrasting water repellency", Eur. J. Soil Sci. 61, 298 (2010). doi: http://dx.doi.org/10.1111/j.1365$\underline{2389.2009 .01224 . x}$

4. L.F. DeBano, "Water repellent soils: a state-of-the-art", Pacific Southwest Forest and Range Experiment Station, Berkley, CA, US Department of Agriculture, Forest Service (1981).

5. L.W. Dekker, C.J. Ritsema, K. Oostindie, D. Moore and J.G. Wesseling, "Methods for determining soil water repellency on field-moist samples", Water Resour. Res. 45, W00D33 (2009). doi: http://dx.doi. org/10.1029/2008WR007070

6. I. Kim, R.R. Pullanagari, M. Deurer, R. Singh, K.Y. Huh and B.E. Clothier, "The use of visible and near-infrared spectroscopy for the analysis of soil water repellency", Eur. J. Soil Sci. 65, 360 (2014). doi: http://dx.doi. org/10.1111/ejss.12138

7. I. McKissock, R.J. Gilkes, R.J. Harper and D.J. Carter, "Relationships of water repellency to soil properties for different spatial scales of study", Aust. J. Soil Res. 36, 495 (1998). doi: http://dx.doi.org/10.1071/S97071

8. M.G. Wallis, D.J. Horne and A.S. Palmer, "Waterrepellency in a New Zealand development sequence of yellow-brown sands", Aust. J. Soil Res. 31, 641 (1993). doi: http://dx.doi.org/10.1071/SR9930641

9. G. Wessolek, H. Stoffregen and K. Täumer, "Persistency of flow patterns in a water repellent sandy soil: conclusions of TDR readings and a time-delayed double tracer experiment", J. Hydrology 375, 524 (2009). doi: http:// dx.doi.org/10.1016/j.jhydrol.2009.07.003

10. N. Jiménez-Morillo, J.A. González-Perez, A. Jordán, L.M. Zavala, J.M. de la Rosa, M.A. Jiménez-González and F.J. González-Vila, “Organic matter fractions controlling soil water repellency in sandy soils from the Doñana National Park (southwestern Spain)", Land Degrad. Develop. 27, 1413 (2014). doi: http://dx.doi.org/10.1002/ $\underline{\text { ldr.2314 }}$

11. C. Chenu, Y. Le Bissonnais and D. Arrouays, "Organic matter influence on clay wettability and soil aggregate 
stability", Soil Sci. Soc. Am. J. 64, 1479 (2000). doi: http:// dx.doi.org/10.2136/sssaj2000.6441479x

12. D. Diehl, "Soil water repellency: dynamics of heterogeneous surfaces", Colloids Surf. A 432, 8 (2013). doi: http:// dx.doi.org/10.1016/i.colsurfa.2013.05.011

13. S.H. Doerr and A.D. Thomas, "The role of soil moisture in controlling water repellency: new evidence from forest soils in Portugal", J. Hydrology 231-232, 134 (2000). doi: http://dx.doi.org/10.1016/S00221694(00)00190-6

14. E. Gimeno-García, J.A. Pascual and J. Llovet, “Water repellency and moisture content spatial variations under Rosmarinus officinalis and Quercus coccifera in a Mediterranean burned soil", Catena 85, 48 (2011). doi: http://dx.doi.org/10.1016/j.catena.2010.12.001

15. J. Mataix-Solera, V. Arcenegui, C. Guerrero, M.M. Jordán, P. Dlapa, N. Tessler and L. Wittenberg, "Can terra rossa become water repellent by burning? A laboratory approach", Geoderma 147, 178 (2008). doi: http://dx.doi. org/10.1016/j.geoderma.2008.08.013

16. J. Mataix-Solera, V. Arcenegui, N. Tessler, R. Zornoza, L. Wittenberg, C. Martínez, P. Caselles, A. Pérez-Bejarano, D. Malkinson and M.M. Jordán, "Soil properties as key factors controlling water repellency in fire-affected areas: evidences from burned sites in Spain and Israel", Catena 108, 6 (2013). doi: http://dx.doi.org/10.1016/j.catena.2011.12.006

17. P.D. Hallett, "An introduction to soil water repellency", in Proceedings of the 8th International Symposium on Adjuvants for Agrochemicals (ISAA2007), Ed by R.E. Gaskin. International Society for Agrochemical Adjuvants, Wageningen (2007).

18. C. Watson and J. Letey, "Indices for characterizing soil-water repellency based upon contact anglesurface tension relationships", Soil Sci. Soc. Am. J. 34, 841 (1970). doi: http://dx.doi.org/10.2136/ sssaj1970.03615995003400060011x

19. B. Stenberg, R.A.V. Rossel, A.M. Mouazen and J. Wetterlind, "Visible and near infrared spectroscopy in soil science", Adv. Agron. 107, 163 (2010). doi: http:// dx.doi.org/10.1016/S0065-2113(10)07005-7

20. C. Pasquini, "Near infrared spectroscopy: fundamentals, practical aspects and analytical applications", J. Braz. Chem. Soc. 14, 198 (2003). doi: http://dx.doi.org/10.1590/ S0103-50532003000200006

21. L. Kooistra, R. Wehrens, R.S.E.W. Leuven and L.C. Buydens, "Possibilities of visible-near-infrared spectroscopy for the assessment of soil contamination in river floodplains", Anal. Chim. Acta 446, 97 (2001). doi: http://dx.doi.org/10.1016/S0003-2670(01)01265-X

22. P.H. Fidencio, R.J. Poppi, J.C. de Andrade and H. Cantarella, "Determination of organic matter in soil using near-infrared spectroscopy and partial least squares regression", Commun. Soil Sci. Plant Anal. 33, 1607 (2002). doi: http://dx.doi.org/10.1081/CSS$\underline{120004302}$
23. F. Deng, M. Knadel, Y. Peng, G. Heckrath, M. Greve and B. Minasny, "Soil profile organic carbon prediction with visible-near infrared reflectance spectroscopy based on a national database", in Digital Soil Assessments and Beyond. CRC Press, Boca Raton, FL, p. 409 (2012).

24. M. Knadel, F. Deng, A. Thomsen and M.H. Greve, "Development of a Danish national vis-NIR soil spectral library for SOC determination”, in Digital Soil Assessments and Beyond. CRC Press, Boca Raton, FL, p. 403 (2012).

25. E.B.A. Bisdom, L.W. Dekker and J.F.T. Schoute, "Water repellency of sieve fractions from sandy soils and relationships with organic material and soil structure", Geoderma 56, 105 (1993). doi: http://dx.doi. org/10.1016/0016-7061(93)90103-R

26. L.W. de Jonge, P. Moldrup and O.H. Jacobsen, "Soilwater content dependency of water repellency in soils: effect of crop type, soil management, and physical-chemical parameters", Soil Sci. 172, 577 (2007). doi: http://dx.doi.org/10.1097/SS.0b013e318065c090

27. M. Kajiura, T. Tokida and K. Seki, "Effects of moisture conditions on potential soil water repellency in a tropical forest regenerated after fire", Geoderma 181, 30 (2012). doi: http://dx.doi.org/10.1016/j.geoderma.2012.02.028

28. M. Knadel, F. Deng, A. Alinejadian, L.W. de Jonge, P. Moldrup and M.H. Greve, "The effects of moisture conditions - from wet to hyper dry - on visible near-infrared soil spectra of Danish reference soils", Soil Sci. Soc. Am. J. 78, 422 (2014). doi: http://dx.doi.org/10.2136/ sssaj2012.0401

29. F. Masis-Meléndez, T.K.K. Chamindu Deepagoda, L.W. de Jonge, M. Tuller and P. Moldrup, "Gas diffusionderived tortuosity governs saturated hydraulic conductivity in sandy soils", J. Hydrology 512, 388 (2014). doi: http://dx.doi.org/10.1016/j.jhydrol.2014.02.063

30. G.W. Gee and J.W. Bauder, "Particle-size analysis", in Methods of Soil Analysis: Part 1. Physical and Mineralogical Methods, Ed by A. Klute. Soil Science Society of America and American Society of Agronomy, Madison, WI, p. 383 (1986).

31. P.M. King, "Comparison of methods for measuring severity of water repellence of sandy soils and assessment of some factors that affect its measurement", Aust. J. Soil Res. 19, 275 (1981). doi: http://dx.doi.org/10.1071/ $\underline{\text { SR9810275 }}$

32. M. Knadel, B. Stenberg, F. Deng, A. Thomsen and M.H. Greve, "Comparing predictive abilities of three visible-near infrared spectrophotometers for soil organic carbon and clay determination", J. Near Infrared Spectrosc. 21, 67 (2013). doi: http://dx.doi.org/10.1255/ jnirs.1035

33. H. Martens and T. Næs, Multivariate Calibration. John Wiley, Chichester (1989).

34. V. Bellon-Maurel and A. McBratney, "Near-infrared (NIR) and mid-infrared (MIR) spectroscopic techniques for assessing the amount of carbon stock in soils - 
critical review and research perspectives", Soil Biol. Biochem. 43, 1398 (2011). doi: http://dx.doi.org/10.1016/j. soilbio.2011.02.019

35. J. Bachmann, M. Deurer and G. Arye, "Modeling water movement in heterogeneous water-repellent soil: 1. Development of a contact angle-dependent water-retention model", Vadose Zone J. 6, 436 (2007). doi: http://dx.doi.org/10.2136/vzj2006.0060

36. K. Kawamoto, P. Moldrup, T. Komatsu, L.W. de Jonge and M. Oda, "Water repellency of aggregate size fractions of a volcanic ash soil", Soil Sci. Soc. Am. J. 71, 1658 (2007). doi: http://dx.doi.org/10.2136/sssaj2006.0284

37. E. Ben-Dor and A. Banin, "Near-infrared analysis as a rapid method to simultaneously evaluate several soil properties", Soil Sci. Soc. Am. J. 59, 364 (1995). doi: http:// $\underline{\text { dx.doi.org/10.2136/sssaj1995.03615995005900020014x }}$
38. G.R. Hunt, "Spectral signatures of particulate minerals in the visible and near infrared", Geophysics 42, 501 (1977). doi: http://dx.doi.org/10.1190/1.1440721

39. J.L. Shonk, L.D. Gaultney, D.G. Schulze and G.E. Van Scoyoc, "Spectroscopic sensing of soil organic matter content”, Trans. ASAE 34, 1978 (1991). doi: http://dx.doi. org/10.13031/2013.31826

40. L.S. Galvão and I. Vitorello, "Variability of laboratory measured soil lines of soils from southeastern Brazil", Remote Sens. Environ. 63, 166 (1998). doi: http://dx.doi. org/10.1016/S0034-4257(97)00135-1

41. E. Ben-Dor "Quantitative remote sensing of soil properties”, Adv. Agron. 75, 173 (2002). doi: http://dx.doi. org/10.1016/S0065-2113(02)75005-0 